\title{
Capital Aset Pricing Model (CAPM) Revisited: The Context of Sharia-based Stocks with the Barakah Risk Premium Variable
}

\author{
Linda Ariany Mahastanti ${ }^{*}$, Marwan Asri², Bernardinus M. Purwanto ${ }^{3}$, \\ Eddy Junarsin 4 \\ ${ }^{1}$ Doctoral Student at Faculty of Economics and Business, Universitas Gadjah Mada \\ ${ }^{1}$ Department of Management, Faculty of Economics and Business, Universitas Kristen Satya \\ Wacana, Salatiga, Indonesia \\ 2,3,4Department of Management, Faculty of Economics and Business, Universitas Gadjah Mada \\ *Corresponding Author: linda.ariany@staff.uksw.edu
}

\begin{abstract}
The purpose of this study is to answer the question about the inconsistency of research results in the field of Islamic stock investment. This study uses literature for digging the uniqueness of Sharia stock investments which cannot be explained completely with a quantitative approach. In the last part of this research, we adjust the Capital Asset Pricing Model (CAPM) in the Sharia capital market based on a literature study. The classical finance theories such as CAPM need to adjust by incorporating the unique characteristics of faith-based investment products. The main difference between faith-based and conventional investment products lies in the presence of religious teachings that underlie the formation of these products. Consequently, investors employ not only the objective risk-and-return analysis to select investment choices, but also the subjective risk-and-return analysis based on Islamic teachings. Subjective gains (nonmonetary) are reflected by the barakah risk premium on which investors initially base their investment selection decisions between sharia-based and conventional stock investment. This research found a new variable called Barakah risk premium and Barakah return. This type of risk and return are very specific which is only found in sharia stock investments
\end{abstract}

Keywords: Barakah risk premium; Barakah return; CAPM; Sharia-based stocks

\section{INTRODUCTION}

The development of faith-based investment products indicates that investors are attracted to invest in assets with unique characteristics that comply with their religious teachings. Investors prefer to invest in categories of stocks that conform with their norms, such as socially responsible, ethical, environmental, and faith-based investing, and to neglect stocks that conflict with their norms, such as sin, polluters, and non-Islamic stocks (Baker \& Nofsinger 2012). 
The phenomena motivate numerous finance scholars to investigate the relationship between religiosity and investment decisions. Several scholars even begin to question whether the traditional finance theories such as Capital Asset Pricing Model and portfolio theories manage to explain the phenomenon (Anand dan Cowton, 1993; Koebrich dan Pfeifer,2013; Canepa and Ibnrubbian,2014). The doubts about several traditional finance theories are an interesting research issue because of the unique characteristics of faith-based investment products such as sharia stocks, sukuk, and Ave Maria mutual funds that align their features with Islamic or Christian/ Catholic teachings. Consequently, investors arguably have different considerations when purchasing these products. In particular, they do not only consider risk and return, but also religiosity. Kuber (2001) found that social norms significantly influence an individual's general behavior, investor preferences (Kim \& Venkatachalam 2011), and financial decissions (Baker \& Nofsinger 2012).

Studies on faith-based financial product investment demonstrate that the traditional finance theories (Perez dan Soydemir,2010; Lyn et al.,2010; Canepa dan Ibnrubbian,2014; Jaiyeoba dan Haron, 2016; Lee dan Veld-Merkeulova, 2016; Mahdzan et al.,2017; AlAwadhi and Dempsey,2017; Castro et al., 2020) have different findings in explaining the relationship between social norm and investment decisions. Previous studies show inconsistent results because they use traditional theoretical approaches to explain faithbased investment. Al-Awadhi and Dempsey (2017) states that non-Islamic stocks in these markets are relatively neglected, have higher returns, lower liquidity, and face higher liquidity risk compared to Islamic stocks. Meanwhile Canepa and Ibnrubbian (2014) findings support the viewpoint that the religious tenets have important bearing on portfolio choices of investors. It is found that Shariah-compliant stocks have higher return and volatility than their non-Shariah compliant counterparts. The inconsistent results mean that there are other factors that influence the expected return on Islamic stocks such as nonmonetary returns as personal values that come from religious teachings.

This study contributes to answering the inconsistency of the results of previous studies by adding a subjective rationality factor as a determining factor for investment in Islamic stocks. Therefore, classical financial theory such as the capital asset pricing model needs to be reviewed to meet subjective rationality on Islamic stocks. The following sections analyze further the above theoretical differences to gain a better understanding of the theoretical gap.

\section{LITERATURE REVIEW}

\section{The View of the Classical Finance Theories in Explaining the Sharia Stock Phenomenon}

The classical finance theories, such as the portfolio and CAPM theories, are based on the rationality assumption. The assumption mainly focuses on objective rationality that argues that individuals choose investments that offer maximum benefits. Plott and Zeiler (2007) propose that rational agents incorporate all available information, the probability of events, and costs and benefits in selecting their preferences. Further, they act consistently in selecting actions that offer the highest utilities. Therefore, the capital asset pricing model (CAPM) provides a useful measure that helps investors determine what sort of investment return they deserve for putting their money at risk on a particular stock based on their maximum utility.

Based on these arguments, individuals will process all available information by considering the risks and benefits to maximize their benefits when making a decision. In 
line with prior studies, Ackert and Deaves (2010) reveal that traditional finance models are based on the neoclassical finance paradigm. The neoclassical paradigm emphasizes utility maximization by incorporating resource limitations. The decision-making process starts with return prediction by estimating the probability of each condition. Thus, a rational decision is considered rational if it manages to realize the maximum expected returns.

Investment decisions taken in uncertain conditions require careful calculations from investors before making investment decisions. Investors make calculations with the maximum utility approach of each available investment option after calculating the expected return on each investment. The maximum utility of each investor will differ depending on the risk preferences that investors have. The underlying theory of these arguments is the expected utility theory (EUT), as introduced by Bernoulli in the $18^{\text {th }}$ century. EUT holds that not all individuals have the same alternatives of each utility calculation that depends on each individual's risk preference. Further, Rubinstein (2006) suggests that several finance theories, especially in investment, are based on EUT that is an old (pre-1950s) finance theory. These theories are the portfolio theory (Markowitz, 1952) or Capital Asset Pricing Model as proposed by Sharpe (1964) and Lintner (1965). Both theories are commonly used to analyze investors' investment behavior, including in sharia-based stocks.

Several studies use traditional finance theories such as CAPM and portfolio theories to examine the role of religiosity in investment decision-making. For example, Perez and Soydemir (2010) compare the returns of sin and faith portfolios and observe that sin portfolios exhibit better performance than faith portfolios. Similar to Perez and Soydemir (2010), Nainggolan et al. (2016) also show the inverse relationship between portfolio performance and ethical stock selection. Al-Awadhi and Dempsey (2017) find that nonIslamic stocks have higher returns, lower liquidity, and face higher liquidity risk compared to Islamic stocks. Besides, Mahdezan et al. (2017) show that religiosity, in general, does not affect individuals' investment portfolio formation. However, Hassan et al. (2005) document different results. Specifically, they analyze the impact of stock selection based on Islamic teachings on the performance of Islamic stocks by using the CAPM theory. They find that the selection of Islamic stocks is not inversely related to stock performance. Meanwhile, in their study in Saudi Arabia, Canepa and Ibnrubbian (2014) demonstrate that religious teachings affect individuals' portfolio formation. Castro et al. (2020) state that Islamic mutual funds outperform socially responsible funds, which then outperform Christianbased mutual funds. Thus, the studies of (Perez and Soydemir,2010; Nainggolan et al., 2016; Mahdezan.,2017:Al-Awadhi and Dempsey,2017) and (Hassan et al.,2005; Canepa and Ibnrubbian,2014; Castro et al.,2020) show inconsistent results.

The inconsistent results of (Perez and Soydemir,2010; Hassan et al.,2005: Canepa and Ibnrubbian,2014; Nainggolan et al.,2016; Mahdezan et al., 2017; Al-Awadhi and Dempsey,2017; Castro et al., 2020) who rely on the traditional finance theories raise the question of the validity of the portfolio and CAPM in finance. In particular, traditional finance theories cannot fully explain market anomalies.

The above discussion shows that traditional views have not effectively explained the phenomenon of investment in faith-based financial products. The inconclusive findings confirm this conclusion. 


\section{Religiosity: Is it a rational decision?}

Based on the above arguments, it is important to further understand whether investment decisions involving religiosity factors are rational. The question is interesting because traditional theory uses specific assumptions. The traditional financial theory assumes that investors are rational in making investment decisions. Another perspective on Islamic finance has a different argument about rationality which is called Islamic Economic Rationalism (IER). IER has a combination of objective (materialistic) rationalism and subjective (non-materialistic) rationalism.

Based on Weber's rationality taxonomy (1968), faith-based decisions are also rational under the subjective rational category. This argument is in line with McCain (1991), who proposes several types of rationality, including subjective rationality. Subjective rationality considers an individual's view or value as a rational decision. Consequently, an actor's intrinsic reason becomes a rational consideration.

Weber (1968) and McCain's (1991) views criticize the narrow definition of rationality. These views motivate many scholars to gain a better understanding of the taxonomy of the meaning of rationality (McCain,1991; Toplak dan Stanovick, 2013). The neoclassical economy perspective (the utilitarian view) considers rationality to maximize benefits received by individuals through completeness and transitory processes (Ackret and Deaves, 2010).

The development of faith-based investment products motivates individuals to incorporate their religious teachings in purchasing these investment products. Their main question is, do these products comply with their religious teachings? If these products comply, these individuals will generate inner satisfaction when purchasing these products. This rationality belongs to the subjective rationality category (Kutchera,1977; Kalberg,1980; Gronow,1988).

According to the explanation of Islamic rationality, Islamic economics has its views to explain consumer behavior. In contrast to the concept of rationality in conventional economics, Hossain (2014) describes a concept called Islamic Economic Rationalism (IER). The same was reviewed by Ramli and Mirza (2007) by dividing the two elements of Islamic rationality into worldviews and personal interests. In the element of personal interest, individuals will fulfill their interests by following sharia compliance. Likewise, IER illustrates that religion is the main determinant, while the source of sharia comes from religion.

A rational Muslim consumer is maximizing success/meaning, which means happiness in the world and the hereafter (Kahf, 2004). This phase is carried out through each activity, including consumption following ethical and religious values following Sharia (Ghassan, 2015). Ghassan explained the benefits of satisfaction channeled through materialistic and metaphysical satisfaction. Consumption-based on Islamic teachings such as using halal goods/services will bring benefits/utilities (Ramli and Mirza, 2007) which can enable maximizing Falah (individuals not solely seeking profit but also trying to achieve victory both in the world and the hereafter).

Therefore, explaining the behavior of investors when they decide to buy Sharia products is not enough just to be seen from the perspective of narrow rationality but also needs to add a view of Islamic rationality that links objective rationality and subjective rationality. Objective rationality is seen from worldly (monetary/materialistic) while 
subjective rationality is heavenly interests seen from Islamic (non-monetary/metaphysical) teachings. This study uses the Islamic Economic rationalism perspective to explain investment decisions in sharia stocks. Religiosity factor is rational used broader rationality concept. Therefore, CAPM is important to revisit because this theory has a narrow rationality assumption.

\section{METHOD}

This study uses a conceptual research framework. Conceptual research is a written or visual representation of an expected relationship between variables. The conceptual framework is generally developed based on a literature review of existing studies and theories about the topic.

This paper uses an adaptation theory approach by expanding existing theories by adding several complementary theories. Through theoretical adaptation, it can capture changes in phenomena or perspectives more quickly. Research that uses a theoretical adaptation approach develops contributions by revising existing knowledge by developing new perspectives on current conceptual variables (MacInnis, 2011). This approach finds the problem of a theory and the concepts that exist in theory. For example, researchers find a phenomenon that makes the theory unable to work correctly, or there are contradictions in empirical research using the theory. Because of that, researchers added new theories to complement existing theories to explain the shift in phenomena or the change in perspective that exists today. Thus, the new theory is used as a tool or method to build a broader conceptual scope (Lukka and Vinnari, 2014).

\section{DISCUSSION}

The Weaknesses of The CAPM Theories in Explaining Faith-Based Investments

According to the rationality taxonomy (Weber, 1968; McCain, 1991), this study positions religiosity as a factor that is considered in individuals' decision-making process with the subjective rationality approach. The next question is then as follows. If religiosity belongs to the rational decision realm, can classical finance theories such as the portfolio or CAPM theories explain faith-based investment phenomenon sufficiently by simply adding religiosity as the additional variable?

Several studies use classical finance theories such as CAPM and portfolio theories to position the religiosity variable as the independent variable directly with investment decisions. However, these studies demonstrate insignificant results (Perez dan Soydemir, 2010; Shahzad dan Quereshi, 2014; Mahdezan et al., 2017). The insignificant results of the use of CAPM theory motivate several scholars to improve the CAPM approach with the sharia capital market context. Derbali (2017) proposes that the relationship between ethical finance and financial performance is still empirically weak. Some studies do not find performance differences between conventional and ethical investments (Baurer et al., 2007). Meanwhile, numerous studies observe that financial performance is affected by factors other than risk-return considerations such as geographical factors, individuals' ethical values, and investment styles (Derbali, 2017).

Consequently, Derbali (2017) criticizes several items of conventional CAPM. First, Islam recognizes risks and considers risks crucial in every investment. Thus, Islam does not recognize the risk-free (Rf) investment because it will contain added values with interest (riba) elements. Second, the risk and uncertainty concepts are also often compared with the gharar concept in Islamic laws. The gharar (uncertainty) concept refers to the inaccuracy and 
information insufficiency of contracting parties. Next, Quthbi (2017) proposes that SCAPM (Shari'a Compliant Asset Pricing Model) is a modified form of CAPM (Capital Asset Pricing Model) that emerges in an interest-based conventional environment. SCAPM seeks to formulate an asset pricing model within a sharia framework. The research relies on SBIS (Sertifikat Bank Indonesia Syariah - Sharia-based Bank Indonesia Certificate) to replace the interest-based Rf component. Meanwhile, Effendi (2016) observes that the inflation-based SCAPM exhibits greater volatility than other SCAPMs. These findings indicate that the inflation-adjusted SCAPM is more profitable and riskier, as suggested by the classical high risk-high return principle.

The above discussion suggests that studies that criticize CAPM to explain shariabased stock investments focus on the use of risk-free rate (Rf) that is considered less appropriate because Islam prohibits riskless returns. They then replace Rf with other components that still comply with Islamic teachings, such as zakat (Cyril and Ri'fat, Ashker,1987; Derbali et al., 2017), sharia-based Bank Indonesia certificate (SBIS) (Quthbi,2017), and inflation (Effendi, 2016).

Meanwhile, Ameer (2015) offers a different perspective by emphasizing different critics to the use of CAPM in the sharia-based stock context. In particular, the research suggests that the CAPM theory assumes that investors can diversify their investment portfolios optimally. Accordingly, investors need to pay attention to systematic risks (beta) that are diversifiable to create optimal portfolios. One that applies this assumption in investing sharia-based stocks cannot create optimal portfolios because individuals can only invest in sharia-based stocks. Thus, the old CAPM model needs to include other risk characteristics that make suboptimal portfolio formation.

Sharia-based stocks exhibit unique characteristics that comply with Islamic teachings. Specifically, Islamic teachings are used to harmonize profits from each individuals' business activity into not only monetary but also nonmonetary aspects (Renneboog et al., 2008). The CAPM model has not adequately explained the unique characteristics that incorporate religious teachings because the model is based on the expected utility theory (EUT).

The EUT approach focuses more on rational factors objectively. At the same time, investments in sharia-based stocks also involve the religiosity factor that can also be categorized as a rational decision from the subjective rationality approach (McCain, 1991). Foley (1987) argues that individuals' beliefs are rational when they can develop arguments from their beliefs. Accordingly, the CAPM theory should not only be adjusted from the risk-free return (Rf) but also the religiosity factor. Higgin (1998) proposes that noneconomic factors are crucial because the classical finance theories largely focus on the riskreturn calculation to maximize individuals' utilities and overlook noneconomic gains that are closely related to individuals' values. In this regard, the CAPM's rationality assumption focuses more on objective rationality but not on subjective rationality.

The religiosity factor will be reflected by the formation of subjective returns based on Islamic teachings. When individuals still choose sharia-based stocks, although these stocks offer lower returns than conventional (non-sharia), then the religiosity factor plays a crucial role in making subjective preferences of individuals loyal to sharia-based financial products. Individuals will opt for sharia-based stocks that promise lower returns because these individuals seek not only market (monetary) returns but also other expected (nonmonetary) returns. In mixed markets, where Islamic and non-Islamic stocks are listed 
on the same stock exchange, Islamic investors trade only stocks of firms that comply with Islamic Shariah (Al-Awadhi and Dempsey, 2017)

Consequently, individuals who buy sharia-based financial products also expect other gains. In this regard, they expect objective returns and other returns that can be labeled as Barakah or berkah returns. Barakah returns will differ for each investor depending on investors' subjective preferences on sharia-based financial products relative to conventional financial products. In turn, the degree of individuals' subjective preferences will depend on their religiosity level.

Based on the above discussion, the formation of the CAPM model cannot solely rely on the EUT theory and also need to rely on the subjective expected utility (SEU) theory as suggested by Savage (1954). SEU measures utilities from individuals' subjective preferences on product choices, and accordingly, utilities have unique values for each individual. Eventually, SEU and IER are the novel theoretical base of the CAPM model by incorporating the subjective rationality factor. Subjective or Barakah returns and risks indicate individuals' subjective rationality.

Barakah returns refer to nonmonetary gains received from investors in terms of inner peacefulness and security because of the awareness of investing in financial products that comply with Islamic teachings. Besides, these investments are also expectedly beneficial to many others. In the formula, Barakah returns are the difference between sharia-based stock returns and conventional stock returns. Barakah returns exist when the returns of shariabased stock returns are lower than those of conventional stocks, and individuals still opt for sharia-based stocks. Thus, investors expect Barakah returns from their investments in sharia-based stocks. Barakah returns will exhibit risk characteristics that can be labeled as Barakah risk premiums. Barakah risk premiums are risks from investing in sharia-based stocks. In particular, the risks emerge because individuals still invest in sharia-based stocks that comply with their religious teachings to generate Barakah returns.

The above discussion confirms Ameer (2015), who argues that portfolios that only consist of sharia-based stocks are not optimal, leading to lower portfolio returns. The suboptimal portfolios are due to adjustments in undiversifiable risks (Barakah risk premiums) when forming portfolios. Barakah risk premium implies that SCAPM needs to adjust the risk-free rate (Rf) and add another risk characteristic. This risk characteristic is identical to sharia-based stocks (Barakah risk premium) as another risk factor besides risk premium.

Regarding the above analysis of risk, discussions on the risk concept in finance were initiated by Markowitz in 1952 with his portfolio diversification concept. Further, William Sharpe, in 1964, added the risk concept in finance by examining the relationship between the returns of individual assets with market returns. The risk is later labeled as market risks or systematic risks that cannot be eliminated by diversification. Based on these arguments, there are two risk types in finance: systematic and unsystematic (firm-specific) risks. Unsystematic risks are closely related to firms' specific conditions that can be reduced by diversification, while systematic risks cannot be eliminated by diversification (market risks). As discussed before, finance theories need to adjust the risk concept to accommodate risk in Islamic finance. Islamic finance introduces the risk concept closely related to God's willing that will result in good or bad outcomes (Noor et al., 2018). God's willing is based on Alquran, especially surah Al-Baqarah, 2:195 (Noor et al., 2018). Surah Al-Baqarah 2: 195 mentions: 
And spend (your wealth) in the way of Allah, and do not throw (yourself) into destruction with your own hands and do good. Surely, Allah loves those who do good. Thus, the definition of risks also depends on scientific disciplines. In the religion discipline, a risk is defined as faithful actions based on God's orders (Althaus, 2015). Consequently, because sharia-based stocks are financial products that are based on Islamic teachings, investors do incorporate not only financial risks but also religion-based ones. Laldin (2013) suggests that Islamic finance considers risk rather differently than conventional finance. These risks are closely related to investors' compliance with every rule in sharia principles.

The Barakah risk premium concept then reflects these risks. Barakah risk premium is a risk characteristic that cannot be avoided in the sharia stock market. This risk exists because individuals prefer investments in sharia-based financial products to conventional stocks, although these products offer lower returns. For example, firms of which stocks are classified into sharia-based ones cannot have business activities that violate sharia principles. In particular, sharia principles forbid business activities that involve uncertainties (gharar) or gambling (maisir); production, distribution, trade, and provision of haram goods and services; and bribery-related transactions (risywah). Besides, sharia stocks also focus on financial ratios, especially by limiting the level of interest-based debt to asset ratio.

Sharia-based financial products are closely related to Islamic teachings that enable the moderating role of individuals' religiosity levels. Religiosity is a situational variable that highly depends on individuals' understanding of Islamic teachings. Accordingly, religiosity will arguably moderate the relationship between Barakah risk premium with individuals' investment portfolio formation. Guiso et al. (2006) and Tabellini (2010) suggest that values, culture, and norms directly affect individuals' attitudes and preferences that will eventually affect decision making. Thus, values derived from religious teachings will result in preferences that will affect investment decision-making.

The new CAPM will adjust to accommodate the role of religiosity through subjective preferences on subjective risks and returns (including Barakah risk premium) by adding the SEU (Subjective Expected Utility) theory and Islamic Economic Rationalism (IER). SEU theory explains decision-making processes in uncertain conditions based on subjective utilities (Savage, 1954). IER explains the behavior consumption of Muslim investors, which alignment between monetary value and non-monetary value (Ghassan, 2015). Those theories incorporate personal utilities and the distribution of probability. Consequently, SEU and IER complement prior investment theories by offering subjective rational views.

\section{CAPM Revisited: The Sharia-based Stock Context with the Barakah Risk Premium Variable}

Further analysis of the relationship between risks-returns and investment decision making reveals that sharia-based stocks exhibit unique return characteristics that cannot be explained by the objective rationality approach of the CAPM theory. The addition of the SEU theory as the basis to explain individuals' behavior to buy sharia-based stocks raises the question as to whether the classical finance theories such as CAPM still can explain the phenomenon. The question is motivated by the fact that the CAPM theory is based on objective rationality that relies on the EUT as the basic theory. Consequently, the CAPM theory needs to be revisited with the following equation (1). 


$$
\begin{array}{ll}
\qquad R_{i t} & =R f_{i t}+\beta_{i t}\left(R m_{i t}-R f_{i t}\right)+\varepsilon_{i t} \\
\mathrm{Rf}_{\mathrm{it}} & =\text { risk-free return } \\
\beta i t & =\text { systematic risk } \\
R m i t-R f i t & =\text { market risk premium } \\
\varepsilon_{i t} & =\text { error }
\end{array}
$$

The CAPM approach above is based on the objective rationality assumption that argues that individuals always seek to maximize expected outcomes when making decisions based on the risk-return considerations. The basic theory of this model is the EUT (Expected Utility Theory). Accordingly, individuals will determine their expected returns based on risk-free returns (Rf) and systematic risks or beta $(\beta)$ that cannot be diversified through portfolios. The calculation of beta involves the market risk premium (Rm-Rf) as the difference between market returns (commonly refer to market indexes such as the IDX composite index in Indonesia) and Rf.

Although several scholars have improved CAPM, the CAPM equation still exhibits numerous weaknesses in explaining sharia-based stock investment. Derbali (2017) highlights the empirically weak relationship between ethical finance and financial performance. Accordingly, Derbali (2017) criticizes the conventional CAPM model. The critique largely focuses on the fact that Islam recognizes risks and even requires risks in each investment. Consequently, Islam does not recognize risk-free investments because such investments likely include interest components. The risk and uncertainty concepts are also often compared with the gharar concept in Islamic law. The gharar concept (uncertainty) refers to information inaccuracy and incompleteness of contracting parties.

Information incompleteness will potentially lead to conflicts between transacting parties. Thus, Cyril and Ri'fat, Ashker (1987) modify the CAPM model by using the zakat percentage of $2.56 \%$ (zakat percentage / 1- zakat percentage) to replace risk-free. Because a Muslim should set aside 2.5\% of his income for zakat, then the risk-free return is calculated with the formula of zakat percentage/ 1 - zakat percentage.

Further, Quthbi (2017) underscores that SCAPM (Sharia-Compliant Asset Pricing Model) is a modified form of CAPM (Capital Asset Pricing Model) that exists in an interestbased conventional environment. SCAPM aims to form an asset pricing model within the sharia framework. The research uses SBIS (Sertifikat Bank Indonesia Syariah - Sharia-based Bank Indonesia Certificate) to replace the interest-based Rf component. Next, Effendi (2016) documents that inflation-based SCAPM that uses inflation exhibits higher volatility than other SCAPMs. These findings show that the inflation-adjusted SCAPM is more profitable but also more risky that is in line with the classical high-risk-high-return principle. The inflation-based SCAPM can then be used to generate the maximum rate of returns. Stock investors can also use this model to generate higher returns. Meanwhile, Derbali et al. (2017) develop a mathematical model of new SCAPM by integrating zakat and excluding short sales. Based on their analysis of ten stock samples, they demonstrate that SCAPM is appropriate and reliable in analyzing the relationship between risks and returns in Shariabased stock markets. The above discussion indicates that studies that use CAPM to investigate sharia-based stocks focus more on inappropriate risk-free rate because Islam forbids risk-free returns. Based on these arguments, $\mathrm{Rf}$ is then replaced with components that comply with Islamic teachings such as zakat (Cyril and Ri' fat, Ashker,1987; Derbali et 
al., 2017), Sharia-based Bank Indonesia Certificate (SBIS) (Quthbi,2017), and inflation (Effendi, 2016).

Consequently, based on the critiques of several scholars on the CAPM, CAPM is then adjusted into the following formula (Cyril dan Ri'fat, Ashker,1987; Effendi, 2016; Quthbi,2017; Derbali et al., 2017) :

$$
R i t=Z i t+\beta i t(R m i t-Z i t)+\varepsilon i t
$$

CAPM in equation (2) has been adjusted to the Islamic teachings, especially regarding the definition of risk-free rate (Rf) that uses zakat. Besides, the formula also modifies the proxy of market returns $(\mathrm{Rm})$ by using a sharia-based stock index. In Indonesia, one can use the Jakarta Islamic Index.

Ameer (2015) proposes that sharia stocks exhibit other risk characteristics because investors only put sharia-based stocks in their stock portfolios. This fact indicates the limitation of CAPM in equations (1) and (2) because an assumption (investors can make optimal portfolios) cannot be satisfied. Suboptimal portfolio formation implies that one needs to consider other risks than beta when forming CAPM for sharia-based stocks (Ameer, 2015). These risks are Barakah risk premium as a systematic risk in sharia-based stock investments.

Barakah risk premium exists because religion-based moral philosophy in engaging business activities motivates investors to more responsibly invest in stocks with higher moral values according to Islamic teachings (Renneboog et al.,2008). Consequently, CAPM needs to adjust by considering religious factors. These religious factors are reflected by the formation of subjective Barakah risks and returns based on Islamic teachings. When individuals still choose sharia-based stocks although the returns of stocks are lower than those of conventional stocks, then the religious factors likely create subjective preferences to motivate individuals to be loyal to sharia-based financial products. Individuals will still select sharia-based stocks with lower returns because they have other expected returns (Barakah returns) that cannot be indicated by market returns.

Barakah risks and returns differ for each investor depending on investors' subjective preferences on sharia-based financial products relative to conventional financial products. The degree of individuals' subjective preferences is affected by individuals' religiosity levels. In this regard, EUT is solely insufficient to explain the phenomenon and needs to be complemented with the subjective expected utility (SEU) theory of Savage (1954). In SEU, utilities are calculated based on individuals' subjective preferences on product choices. Accordingly, utility values are unique for each individual.

The above discussion implies the adjustment of SCAPM from the Barakah risks and returns approach. However, such adjustment from the subjective rationality aspect through the formation of Barakah risk and return is still relatively understudied. Currently, CAPM includes the risk premium term that refers to the compensation required by risk-averse market participants to compensate inherent uncertainties in cash flows of an asset or liability, with a similar analogy, highly religious investors who strictly adhere to Islamic teachings are more likely to select sharia-based than conventional stocks to avoid being sinful due to not accepting Barakah returns. Barakah risk premium is the difference between the market returns of conventional stocks and those of sharia-based stocks. The basic assumption of this risk premium is that because the returns of sharia-based stocks are lower than those of conventional stocks, individuals with only objective rationality will prefer 
conventional stocks to sharia-based ones. However, because they have subjective rationality based on Islamic teachings, highly religious individuals are more likely to select shariabased stocks than conventional ones, although sharia-based stocks offer lower returns because of religious motivation.

Individuals' preferences of sharia-based stocks over conventional stocks with higher returns result in the suboptimal formation of the efficient frontier, especially when two stocks with similar risk characteristics produce different results. For example, an investor is confronted with two stock choices: beer and mineral water companies. The risk and return of the beer stock are $2 \%$ and $6 \%$, respectively. Meanwhile, the risk and return of the mineral water stock are $2.03 \%$ and $4 \%$, respectively. An investor who seeks Barakah returns tends to receive Barakah risks. Accordingly, she likely chooses the mineral water stock, although it offers a lower return $(4 \%)$ with a similar risk level.

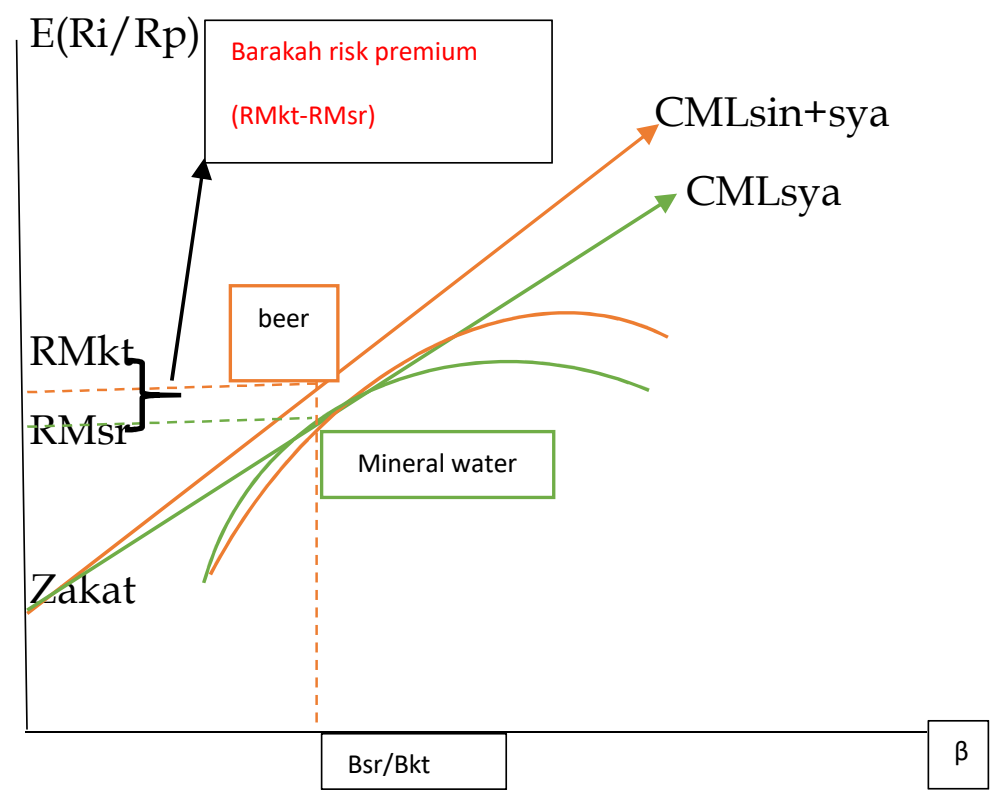

Figure 1. Capital Market Line and Barakah Risk Premium

Such an action leads to suboptimal portfolio formation (figure 1) and the formation of lower efficient frontier relative to other portfolios that exclude conventional stocks with higher returns, albeit similar risk levels. Efficient frontier refers to low-risk portfolios that offer certain expected returns or portfolios with certain risk levels that offer higher returns (Edirisinghe (2013). The efficient frontier is not optimal when there is a difference between market returns that include higher-returns conventional stocks and the market returns of sharia-based stocks that offer lower returns. The difference itself is also labeled as Barakah risk premiums. Following equation (3).

$$
R M_{k t}-R M_{s r}
$$

RMkt $=$ the market returns of conventional stocks that offer higher returns than shariabased stocks 
RMsr $=$ the market returns of sharia-based stocks that offer lower returns than conventional stocks

Individuals' religiosity levels will manifest when they are confronted with unprofitable choices. Will they still choose sharia-based stocks, although these stocks offer lower returns than conventional stocks? Accordingly, Barakah risk premiums are inversely related to required returns in the new SCAPM. The inverse relationship shows that higher Barakah risk premiums imply higher Barakah returns. Thus, when investors seek to avoid Barakah risks, they tend to select sharia-based stocks that offer lower returns to acquire Barakah returns. Consequently, these actions result in lower portfolio returns than those of portfolios that include higher-returns conventional stocks. In all cases, an aggregate sin portfolio always outperforms constrained investments, clearly suggesting an ethical dilemma faced by investors (Al-Awadhi and Dempsey, 2017: Castro et al., 2019)

Barakah returns and risk premium are subjective risk and return categories because they depend on individuals' beliefs in their religious teachings. Therefore, the SEU theory with subjective rationality view better explains Barakah risks and returns. Consequently, the improved CAPM incorporate subjective rationality view with the following equation (4).

$$
E(R i t)=Z i t+\beta 1_{i t}\left(R M_{s t}-Z_{i t}\right)+\beta 2_{i t}\left(R M k t_{i t}-R M s r_{i t}\right)+\varepsilon_{i t}
$$

$Z \quad=$ zakat $\mathrm{Rm}$

$R M S \quad=$ the return markets of sharia-based stocks (JII)

$R M S r=$ the return markets of sharia-based stocks that offer lower returns than conventional stocks

RMkt = the return markets of conventional stocks that offer higher returns than shariabased stocks

$E$ (Rit) $=$ Expected returns

$E \quad=$ error

In equation (4), $\mathrm{Rf}$ is replaced by zakat, while $\mathrm{Rm}$ is generated from the sharia-based stock index, such as the Jakarta Islamic Index (JII). Besides modifying the objective rationality component, the SCAPM also adds the subjective rationality factor by including the Barakah risk premium factor. This factor also related to Islamic rationality concepts for maximizing Falah.

Muslim investors have sharia-based and conventional stock investment options when making initial investment decisions. The initial consideration of investments determines the risk and return profiles of the existing stocks. If a conventional stock (say, a beer stock) offers a $6 \%$ return and a mineral water stock offers a $4 \%$ return with similar risk characteristics, investors will face a Barakah risk. Investors who receive Barakah risks to expect Barakah returns will buy the mineral water stock, although this stock offers lower returns. Hence, investors' portfolio formation is not optimal and eventually offers lower portfolio returns than portfolios that include both conventional and sharia-based stocks.

After making decisions based on Barakah risks and returns, investors who only invest in sharia-based stocks will form their portfolios by considering market risks from the index of all sharia-based stocks. Hence, the formation of the sharia-based stock portfolios is affected by two risk types, namely Barakah risks that are based on religious teachings and market risks that rely on financial approach. Market risks, in this context, market risk premiums, are positively related to the formation of sharia-based stock portfolios. 
Meanwhile, Barakah risk premiums are negatively related to the formation of sharia-based stock portfolios. These relationships cause the performance of sharia-based stocks is lower than that of conventional stocks.

Next, the equation model (4) will be adjusted with individuals' religiosity levels due to Barakah risk premiums. In this regard, highly religious individuals exhibit subjective preferences that prefer sharia-based than conventional stocks. Religiosity will strengthen or weaken the relationship between Barakah risk premiums and the returns of sharia-based stock portfolios. When individuals have higher (lower) subjective preferences on shariabased products, the relationship between Barakah risk premiums and the required returns of sharia-based stock portfolios strengthens (weakens).

Subjective preferences exist when:

$$
\begin{aligned}
& R M_{s r}<R M_{k t} \ldots \ldots \ldots \ldots \ldots \ldots \ldots \ldots \ldots \ldots \ldots \ldots \ldots \ldots(5) \\
& \sigma_{s r}=\sigma_{k}
\end{aligned}
$$

Based on equations (5) and (6), when individuals still choose sharia-based stocks, although these stocks offer lower returns than conventional stocks for similar risk levels, a factor likely moderates the effect of individuals' subjective preferences on the choice of sharia-based financial products. This factor more strongly motivates individuals to buy sharia-based stocks. A factor that affects individuals' higher subjective preferences on sharia-based stocks is individuals' religiosity.

This conceptual research demonstrates the extent of religiosity affects the selection of sharia-based financial products by comparing the returns of sharia-based and conventional stocks (that are prohibited by religion, such as cigarette companies' stocks). Therefore, from equation (4) above, the volatility of Barakah risk premiums is the new variable. The volatility of Barakah returns is a consequence of uncertain conditions when investing in sharia-based stocks because the returns of sharia-based stocks change continuously.

The presence of new variables (Barakah risk premium) expectedly improves CAPM in explaining faith-based investments. The religiosity, through subjective preferences, will strengthen or weaken the relationship between the Barakah risk premium variable and the expected returns of sharia-based stock portfolios. Thus, previous findings are inconclusive in illuminating faith-based investments based on the conventional finance theories because they have not incorporated the subjective rationality element as reflected by the Barakah risk premiums

\section{CONCLUSIONS}

The development of faith-based investment products such as sharia-based capital markets raises doubts about the ability of several classical finance theories to explain the phenomenon. These theories include the portfolio and capital asset pricing model or CAPM theories. The classical theories assume that individuals think rationally when making decisions that they use risks and returns as the main considerations when making investment decisions. Individuals often do not solely consider risks and returns when making investment decisions in faith-based financial products such as sharia-based stocks. In this respect, individuals also consider other factors that fit with their personal values from their religious teachings. Therefore, the purpose of this study is to fill the gap of traditional theories such as CAPM when use to explain investment in sharia stocks. 
This study found that personal values have not sufficiently reflected by several classical finance theories, such as CAPM. Therefore, the CAPM theory needs improving to adjust to the faith-based investment context. This study adjusts CAPM by adding a variable of Barakah risk premium. Barakah risk premium is a variable that exists from individuals' religiosity levels. Individuals do expect not only monetary returns but also nonmonetary ones when investing in sharia-based stocks. The returns are labeled as Barakah returns. These returns are computed from the difference between the returns of sharia-based and conventional stocks. When investors choose sharia-based stocks, although these stocks offer lower returns than conventional stocks, these investors arguably expect other gains or labeled as Barakah returns that later cause a new risk type, namely Barakah risk premium. Further, individuals' religiosity levels affect their subjective preferences that will eventually weaken or strengthen the effect of Barakah risk premium on the required returns of sharia-based stocks.

This research still focuses on the results of a literature review, further research can prove subjective rationality (the risk premium of barakah) either by using archival data approaches or experimental studies.

\section{REFERENCES}

Ackert,L.F., and R.Deaves.(2010), Behavioral Finance: Psychology, Decision Making, and Markets, South-Western Cengage Learning.

Akerlof, George A. (2007), "The Missing Motivation in Macroeconomics", American Economic Review. Vol. 97 No.1,pp. 5-36. https://doi.org/10.1257/aer.97.1.5

Althaus, C. E. (2005), "A disciplinary perspective on the epistemological status of risk", Risk Analysis, Vol.25, pp. 567-588. https://doi.org/10.1111/j.1539-6924.2005.000625.x

Al-Awadhi, A. M., \& Dempsey, M. (2017). “Social norms and market outcomes: The effects of religious beliefs on stock markets", Journal of International Financial Markets, Institutions and Money, Vol 50, pp.119-134. https:// doi.org/10.1016/j.nir.2020.08.002

Ameer Rashid.(2015)," Idiosyncratic Rik of Investing in Islamic Capital Market Equities", The Journal of Investing Summer, Vol.24 No. 2, pp. 79-89.

Anand, P., \& Cowton, C. J. (1993), "The ethical investor: Exploring dimensions of investment behaviour",Journal of Economic Psychology, Vol. 14 No.2, pp.377-385. https:/ / doi.org/10.1016/0167-4870(93)90007-8

Baker, H. K. \& Nofsinger, J. R. (2012), Socially Responsible Finance and Investing: Financial institutions, Corporations, Investors, and Activists, John Wiley \& Sons

Bauer, R., Derwall, J. and Otten. R. (2007),"The ethical mutual fund performance debate:New evidence from Canada". Journal of Business Ethics, Vol.70 No.2, pp.111124. https:// doi.org/10.1007/s10551-006-9099-0

Boudon, Rymond. (1989), "Subjective Rationality and the explanation of Social Behavior", Rationality and Society, Vol.1 No.2, pp.173-196. https:// doi.org/10.1177/1043463189001002002

Canepa.,A Ibnrubbin. (2014), “Does Faith Move Stock Markets? Evidence from Saudi Arabia", Economics and Finance Working paper Series, Vol.14 No.1, pp.1-29. 
Castro, E., Hassan, M.K., Rubio, J.F. and Halim, Z.A. (2020), "Relative performance of religious and ethical investment funds", Journal of Islamic Accounting and Business Research, Vol. 11 No. 6, pp. 1227-1244. https://doi.org/10.1016/j.bir.2020.08.002

Charles R. Plott and Kathryn Zeiler. (2007), "Exchange Asymmetries Incorrectly Interpreted as Evidence of Endowment Effect Theory and Prospect Theory?", American Economic Review, Vol.97 No.4, pp. 1449-1470.

Cyril, T and Ri'fat, K. (1987), "The Shari'ah and Its Implications for Islamic Financial Analysis:AnOpportunity to Study Interactions Among Society, Organization and Accounting", The American Journal of Islamic Social Sciences, Vol. 4 No.1, pp.101-115.

Derbali Abdelkader, Abderrazek Khaldi, Fathi Jouini. (2017), “Shariah-compliant capital asset pricing model: New mathematical modeling", Journal of Asset Management, Palgrave Macmillan, Vol.18 No.7, pp. 527 - 537. https://doi.org/10.1057/s41260-0170051-x

Effendi, Kharisya Ayu.(2016), “Optimalisasi Shari'a Compliant Asset Pricing Model terhadap Rate of Return pada Jakarta Islamic Index". Jurnal Manajemen, Vol.20 No.3, pp. $1-24$.

Foley, R. (1987), "Epistemic rationality and scientific rationality", International Studies in the Philosophy of Science, Vol.1 No.2, pp.233-250.

Ghassan, H. B. (2015), "Islamic Consumer Model, Fairness Behavior and Asymtotic Utility", Munich Personal RePEc Archive, pp.1- 39.

Gronow,Jukka.(1988), “The Element of Irrationality: Max Weber's Diagnosis of Modern Culture", Acta Sociologica, Vol.31 No.4, pp. 319-331. https:// doi.org/10.1177/000169938803100403

Guiso, Luigi, Paola Sapienza and Luigi Zingales. (2006), “ Does culture affect economic outcomes?", Journal of Economic Perspectives, Vol. 20 Noo.2, pp.23-48.

Hassan A.,Antoniou A,Paudyal.K. (2005), "Impact of Ethical Screening on Investment Performance:The Case of The Dow Jones Islamic Index', Islamic Economic Studies, Vol.12 No.2, pp.68-97.

Higgins ET. (1998). Promotion and prevention: regulatory focus as a motivational principle. In Advances in Experimental Psychology, San Diego, CA; 1-46: Mark PZ (ed.) Academic Press.

Hossain, B. .(2014), "Economic Rationalism and Consumption: Islamic Perspective", International Journal of Economics, Finance and Management, pp.273 - 281.

Jaiyeoba, h.b, and haron,R.(2016), "A Qualitative Inquiry in to the Investment Decision Behavior of the Malaysian Stock Market Investor", Qualitative Research in Financial Market, Vol. 8 No.3, pp. 246-267.

Johnson, R., B. \& Onwuegbuzie, A., J. (2004), “ Mixed Methods Research: A Research Paradigm Whose Time Has Come", Educational Researcher, Vol.33 No.7, pp. 14-26. https:// doi.org/10.3102/0013189X033007014

Kahf, M. (2004). The Demand Side or Consumer Behavior: Islamic Perspective. 
Kalberg, Sthepen.(1980), “Max Weber Type of Rationality: Cornerstone for The Analysis of Rationalization Process in History", The American Journal of Sociology, Vol.85 No.5, pp. 1145-1179.

Kim, I. \& Venkatachalam, M. (2011), 'Are sin stocks paying the price for ac650 counting sins?', Journal of Accounting, Auditing \& Finance 26(2), 415-44. https:// doi.org/10.1177/0148558X11401222

Koebrich Leon \& Christian Pfeifer. (2013). "Religious Activity, Risk Taking Preferences, and Financial Behaviour: Empirical Evidence from German Survey Data," Working Paper Series in Economics 269, University of Lüneburg, Institute of Economics.

K“ubler, D. (2001), 'On the regulation of social norms', Journal of Law, Eco655 nomics, and Organization 17(2), 449-476

Kumar.,A, Page Jeremy,K, Spalt,Oliver G. (2011), “Religious beliefs, gambling attitudes, and financial market outcomes", Journal of Financial Economics, Vol.102 No. 1, pp. 671708. https://doi.org/10.1016/j.jfineco.2001.07.001

Laldin, M. A. (2013), Shariah non-compliance risk. In S. Archer \& R. A. A. Karim (Eds.), Islamic finance: The new regulatory challenge (2nd ed., pp. 237-260). Singapore: John Wiley.

Lee,B. and Veld Merkuelova.(2016), "Myopic Loss Aversion in Stock Investment: An Empirical Study of Private Investor", Journal of Banking and Finance, Vol.70 No.3, pp. 235-246. https://doi.org/10.1016/j.jbankfin.2016.04.008

Lehrer, E. L. (2004), "Religion as a Determinant of Economic and Demographic Behavior in the United States', Population and Development Review, Vol.30 No.4, pp. 707-726. https:/ / doi.org/10.1111/j.1728-4457.2004.00038.x

Leon.A.J,Pfeifer.C.(2013), “Religious Activity, Risk Taking Preference, and Financial Behavior: Empirical Evidence form Germany Survei Data", Working paper Series in Economics University of Luneburg. ISSN 1860-5508.

Lintner, J. (1965), “The Valuation of Risk Assets and the Selection of Risky Investments in Stock Portfolios and Capital Budgets", The Review of Economics and Statistics, Vol. 47 No.1, pp. 13-37. https://doi.org/10.2307/1924119

Lukka, K., \& Vinnari, E. (2014). Domain theory and method theory in management accounting research. Accounting, Auditing $\mathcal{E}$ Accountability Journal, Vol.27 No.8, pp 1308-1338. https:/ / doi.org/10.1108/AAAJ-03-2013-1265

Lyn, Esmeralda,O and Zychowich, Edward,J.(2010) “The Impact of Faith Based Screen on Investment Performance", Journal of Investing, Vol. 19 No.3, pp.136-142.

Machina Mark,J and Schmeidler David.(1992), "A More Robust Definition of Subjective Probability", Econometrica, Vol.60 No.4, pp. 745-780. https:// doi.org/10.2307/2951565

MacInnis, D. J. (2011). A framework for conceptual contributions in marketing. Journal of Marketing, Vol .75 No.4, pp 136-154. https:// doi.org/10.1509/jmkg.75.4.136 
Mahdzan,N.S, Rozimah,Z,Rosmawani,C.H, Noor A.S. (2017), "Islamic Religiosity and Portfolio Allocation: The Malaysian Context.", International Journal of Islamic and Middle Eastern Finance and Management, Vol.10 No.5, pp.434-452.

Markowitz, H. (1952), "Portfolio Selection", The Journal of Finance, Vol.7 No.1, pp.7791. https://doi.org/10.2307/2975974

McCain ,Roger A. (1991), "Deontology, Consequentialism, and Rationality”, Review of Social Economy, Vol.49 No.2, pp.168-195. https:/ / doi.org/10.1080/00346769100000015

Mabrouk,H.B, BouriA.(2011), "Is the CAPM Dead or Alive? A Meta Analytical Approach", Journal of Business research, Vol.5 No.1, pp.50-72.

Nainggolan Yunieta, Janice How and Peter Verhoeven.(2016), “Ethical Screening and Financial Performance: The Case of Islamic Equity", Journal of Business Ethics, Vol.137 No.1, pp.83-99 https://doi.org/10.1007/s10551-014-2529-5

Noor Nurul S,M, A G Ismail, and M Hakimi Shafiai. (2018), "Shariah Risk: Its Origin, Definition, and Application in Islamic Finance", SAGE open, Vol.1 No.1, pp 1 -12, https:// doi.org/10.1177/2158244018770237

Noussair, Charles, Stefan T. Trautmann, Gijs van deKuilen and Nathanael Vellekoop(2013), "Risk Aversion and Religion", J Risk Uncertain, Vol. 47 No. 3, pp.165-183. https:// doi.org/10.1007/s11166-013-9174-8

Perez Liston, D. and Soydemir, G. (2010), "Faith-based and sin portfolios: An empirical inquiry into norm-neglect vs norm-conforming investor behavior", Managerial Finance, Vol.36 No.10, pp. 876-885. https:// doi.org/10.1108/03074351011070242

Plott, Charles R. and Zeiler, Kathryn. (2007),"Exchange Asymmetries Incorrectly Interpreted as Evidence of Endowment Effect Theory and Prospect Theory?", American Economic Review, Vol.97 No.4, pp.1449-1460.

Quthbi, Zainul Hasan. (2017), “Analisis Saham Syariah Efisien dengan Pendekatan Shari'a Compliant Asset Pricing Model (SCAPM) pada Jakarta Islamic Index (JII). Ekonometrika", Jurnal Ekonomi Islam, Vol.8 No.1, pp.1-22. https:// doi.org/10.21580/economica.2017.8.1.1829

Ramli, A. M., \& Mirza, A. A. (2007), “The Theory of Consumer Behavior: Conventional vs. Islamic",2nd Islamic Conference ( $i E C O N S$ ) 2007. Islamic Science University of Malaysia

Renneboog, Luc and Christophe Spaenjers . (2012), "Religion, economic attitudes, and household finance", Oxford Economic Papers, Vol.64 No.1, pp.103-124.

Rubinstein Mark. (2006). A History of Theory of Investments. New Jersey: John Wiley \& Sons, Inc., Hoboken.

Savage,L.J.(1954). The Foundation of Statistics.New York: Jhon Willey and Sons.Revised and Enlarged Edition, New York:Dover Publication,1972.

Shanteau J \& Pingenot A (2009), Subjective Expected Utility Theory, In M. W. Kattan (Ed.), Encyclopedia of Medical Decision Making

Shahzad, S. K., Awan, H. M., \& Qureshi, A. S. (2014), "Influence of religion and culture on investment behaviour of Muslim investors in Pakistan",International Journal of Social 
Entrepreneurship and Innovation,Vol. 3 No.2, pp. 85-97. https:// doi.org/10.1504/ijsei.2014.064823

Sharpe, W. F. (1964), "Capital Asset Prices: A Theory Of Market Equilibrium Under Conditions Of Risk", The Journal of Finance, Vol.19 No.3, pp.425442. https:// doi.org/10.1111/j.1540-6261.1964.tb02865.x

Tabellini, Guido (2010), "Culture and Institutions: Economic Development in the Regions of Europe", Journal of the European Economic Association, Vol.8 No.4, pp. 677-716. https:// doi.org/10.1111/j.1542-4774.2010.tb00537.x

Toplak,ME.,West,R,F\&Stanovic K,E.(2013), Assesing the Development of Rationality, In H MArkovits (Ed). The Development of Psycology of reasoning and Decision making.NY: Psycological Press.

Weber, Max.(1968), Economy of Society. An Outline of Interpretative Sociology, New York: Badminster Press.

Yellen, J.1.,and G.a Akerlof. (1987), "Rational Model of Irrational Behavior", The American Economic Review, Vol.77 No.2, pp.137-142. 